\title{
Assessing the Status of Fine and Applied Arts Curriculum in Human Capacity Building in North Eastern Nigeria
}

\author{
Goshi M. Shedrach \\ Department of Fine And Applied Arts, College of Education, Azare-Bauchi State, Nigeria
}

\begin{abstract}
Art is everything in life, no nation or society survives without art. It can also be seen as a natural and immediate form of expression. It equips the teeming youths or the citizenry with job opportunities and reduces unemployment rate, but on the other hand, unemployment and national insecurity is drastically on the increase. This necessitated the assessment of fine and applied arts curriculum in terms of human capacity building in north eastern Nigeria. Two research questions were formulated to guide the researcher in the study. A descriptive survey research design was adopted to seek the opinion of the respondents. A structured questionnaire was used to collect data from 50 students and 12 lecturers from three colleges of education from three states of north eastern Nigeria, these are:- Federal College of Education (Tech) Potiskum, Yobe State, Federal College of Education (Tech) Gombe, Gombe State and College of Education Azare, Bauchi State. The total of 62 subjects was used as the population. Statistical mean was used to answer the research questions and t-test was used to analyze the hypothesis at 0.05 level of significance. In the findings, infrastructure and facilities are so much lacking. Some recommendations were made one of which is: there is the need for an analytical curriculum.
\end{abstract}

Keywords: Art; students; lecturers; college

\section{INTRODUCTION}

Unavailability of human capacity building and unemployment in Nigeria is on the increase daily. Mutari and Ademola (2007) states that, the number of jobs available is not equal to the number of graduate which comes out of our various educational institutions every year. It is in line with the above that the Federal Government is trying all possible means to curtail the sad state by introducing some programmes geared towards job creation and human capacity building. Human capacity building is a conceptual approach to development that focuses on understanding the obstacles that inhibits people from realizing their developmental goals while enhancing the abilities that will allow them to achieve measurable and sustainable results. To define art in a simple term could be very difficult. Such a definition may not be embracing enough to represent all what art stands for.

Art is a very wide human activity involving some skills. It is imaginative, creative and aesthetic in nature. One uncontroversial thing about art is that, it affects almost every aspects of man's life. If we say art is beauty, what happens to a horrifying mask? Is it beautiful? Obviously, it is not, but it is an art work. It's for that reasons I want to agree that art deals 
with both beautiful and ugly things. A work of art is defeated if it does not satisfy or qualify what it is meant for. In summary therefore, Art is the ability of one to express himself/herself through a medium. In other word, Art means self expression through a medium. From the foregoing, Domba (2005) defines arts in the following ways:

- Art is the creation or expression of what is beautiful.

- Art is a visual representation of human thought or feelings that satisfies one's craving for good.

- Art is the act of making skillful use of materials to produce things for human use and pleasure.

From the above definitions, art is therefore a visual language unhampered by words, an ideal medium for communication; it speaks all languages and as well appreciates what is beautiful, ugly, horrifying and anything appealing to ones sense of beauty. Art by nature incorporates all other subjects in the school curriculum other subjects cannot easily divorced from arts. A common belief of the artist is that the essence of man's existence is Art-as manifested in his daily activities. Therefore, the involvement of fine and applied arts in the provision comfort, pleasure and of course technological development for mankind cannot be underestimated.( Afolabi 2001).

Fine and Applied Arts Education is an aspect among other areas introduced by the Federal Government of Nigeria to achieve its numerous goals. This system of education is enshrined in the National Policy on Education. It is viewed as an instrument for national development. Therefore, among the expectations of the policy is exposing the students to the trade which will provide them with skills that can make them highly productive, competent and therefore, becomes employable in either paid or self employed. This expectation can only be achieved through a planned curriculum.

Curriculum is a series of intended learning experiences through which educational institutions endeavor to realize the hopes of the society. Okoro(2006) states that, it is the totality of all the experience, that the students are exposed under the direction of the school. Narrowing it to the goal of vocational and technical education, it is a course designed to achieve a particular purpose. In other to achieve the objective of vocational and technical education, the curriculum has the following components: occupational studies, professional studies and general studies. The occupational component prepares the prospective students for proficiency in the occupational areas e.g. painting and sculpture in the aspect of Fine Arts, while ceramics, graphic and textiles design which also serve the aspect of Applied Arts. All the students in these areas are expected to be professionally and occupationally competent in all their areas of endeavour.

These objectives can only be achieved through a functional, relevant and a well planed curriculum. This type of curriculum can lead to the production of manpower needed by the nation Saidu (2007). The relevant curriculum helps in making a nation to proudly depend on her art and artist for her artistic and technological development; it reduces the rate at which a country depends on other countries for raw materials and expatriates. It can also mean that, relevant curriculum promotes not only room for human capacity building but also enhances national security of a nation.

Lastly, Dogara and Joel (2012), further explained that signs and signals have indicated that the programmes which the country trusted as a vehicle to rescue her from all the society menace, making its citizens self reliant and creating job opportunity is faulty. From the foregoing therefore, since the curriculum is the master plan of what is expected out of any 
successful programme, there is need to assessed whether the curriculum is relevant in human capacity building or not.

\section{Statement of the problem}

Art is everything in life, no nation or society survives without art. It equips the teeming youths or the citizenry with job opportunities and reduces unemployment rate, but on the other hand, unemployment and national insecurity is drastically on the increase. This is because the graduates of fine and applied arts that graduate from colleges of education lack the appreciable or sealable skills that will make them become self reliant or be employed in the labour market. Nuru (2008), Dogara and Joel (2012) stressed that graduates of vocational and technical education (fine and applied arts inclusive) graduates without any appreciable skills. Williams (2009), also lamented that employers of labour fine problem employing workers or rather graduate of vocational and technical education because they lack the skills needed for the job. Umar and Magaji, (2010) attributed this sad state to irrelevant curriculum while Jibrin and Mohammed (2007) concluded that the curriculum is not functional. Therefore, there is the need to assess the relevance of the curriculum of vocational and technical education with fine and applied arts inclusive.

\section{Purpose of the study}

The purpose of the study is to find out the opinions of lecturers and students of colleges on the curriculum of fine and applied arts with respect to human capacity building in North Eastern Nigeria. Specifically, the study intends to achieve the following objectives:

1. Determine the status of fine and applied arts curriculum in human capacity building in North-eastern Nigeria.

2. Determine the status of infrastructure and facilities in colleges of education in Northeastern Nigeria.

\section{Research questions}

1. What is the status of fine and applied arts' curriculum in human capacity building in colleges of education in North-eastern Nigeria?

2. What is the status of infrastructures and facilities in colleges of education in Northeastern Nigeria?

\section{Hypotheses}

1. There is significance difference between the mean responses of lecturers and students in the status of fine and applied arts common in human capacity building.

2. There is no significance difference between the mean responses of lectures and students in the responses on the status of infrastructure and facilities in colleges of education in North-eastern Nigeria.

\section{METHODOLOGY}

Research design- descriptive research design was used for the study to seek the opinion of the despondence. The design was found suitable in seeking the opinion of the despondence Sambo (2005). 


\section{Area of the study}

The area of the study was North-eastern Nigeria which comprises of six (6) states namely; Bauchi, Gombe, Yobe, Borno, Adamawa and Taraba states. Out of which three colleges in three states were selected ie, Bauchi, Gombe and Yobe state.

\section{Population of the study}

The population for the study was 62 comprising of 50 students and 12 lecturers.

\section{Sampling techniques}

Random sampling technique was used and three institutions were selected i.e., Federal College of Education( Technical) Potiskum, Yobe State, Federal College of Education (technical) Gombe, Gombe State and College of Education Azare, Bauchi State.

\section{Instrument}

A structured questionnaire was used to obtain data for the study.

\section{Method of data analyses}

The research questions were analyzed using mean while t-test was used to test the hypotheses realized.

\section{Decision rule}

Ratings below 3.00 is regarded as being rejected or disagreed with, while rating above 3.00 is regarded as being agreed with or accepted.

\section{RESULT PRESENTATION}

The data collected related to the study was presented based on the research questions as shown below.

Research question 1 what is the status of fine and applied arts' curriculum in human capacity building in colleges of education in North-eastern Nigeria?

Table 1. Shows the mean rating of responses of the curriculum status.

\begin{tabular}{|c|c|c|c|c|c|}
\hline S/No & ITEMS & LECT & STD & G/mean & REM \\
\hline 1 & Provision for subsidiary courses & 3.2 & 3.0 & 3.10 & Agreed \\
\hline 2 & Curriculum comprises of all trades & 3.0 & 2.2 & 2.60 & Disagree \\
\hline 3 & Curriculum is reviewed to current issues & 2.2 & 2.0 & 2.10 & Disagree \\
\hline 4 & Curriculum in harmony with others & 3.2 & 2.2 & 2.70 & Disagree \\
\hline 5 & Curriculum provides skill acquisition & 2.0 & 3.2 & 2.60 & Disagree \\
\hline
\end{tabular}




\begin{tabular}{|c|c|c|c|c|c|}
\hline 6 & Curriculum is comprehensive & 2.1 & 3.0 & 2.55 & Disagree \\
\hline 7 & Curriculum has met the needs of the Nigerians & $2 . .2$ & 3.1 & 2.65 & Disagree \\
\hline 8 & The curriculum contain current issues & 2.0 & 3.2 & 2.60 & Disagree \\
\hline
\end{tabular}

Table 1 above revealed that the responses of the respondents related to the status of fine and applied arts curriculum in human capacity building in colleges of education in Northeastern Nigeria rated item 1 as agreed with a grand mean of 3.10, while items 2-8 as disagree with a grand mean ranging from $2.10-2.70$.

Research question 2. What is the status of infrastructures and facilities in colleges of education in North-eastern Nigeria?

Table 2. Mean rating of responses status of infrastructures and facilities.

\begin{tabular}{|c|c|c|c|c|c|}
\hline S/No & ITEMS & LEC & STD & G/Mean & REM \\
\hline 9 & Adequacy of workshops & 3.0 & 3.1 & 3.05 & Agree \\
\hline 10 & Center for appropriate technology & 1.0 & 2.1 & 1.55 & Disagree \\
\hline 11 & Educational technology center & 2.0 & 2.1 & 2.05 & Disagree \\
\hline 12 & Adequate halls & 3.2 & 3.0 & 3.15 & Agree \\
\hline 13 & Adequate classes & 3.1 & 3.0 & 3.05 & Agree \\
\hline 14 & Central library stocked & 2.1 & 2.2 & 2.15 & Disagree \\
\hline 15 & Adequate hostel blocks & 2.0 & 1.2 & 1.60 & Disagree \\
\hline 16 & Adequate studios for practical & 2.2 & 2.1 & 2.15 & Disagree \\
\hline 17 & Adequate stores to workshops & 2.3 & 2.0 & 2.15 & Disagree \\
\hline 18 & Adequate machines & 3.0 & 2.3 & 2.65 & Disagree \\
\hline 19 & Adequate power tools & 2.2 & 2.1 & 2.15 & Disagree \\
\hline 20 & Adequate hand tools & 2.1 & 2.2 & 2.50 & Disagree \\
\hline 21 & Consumables procured & 1.0 & 2.0 & 1.50 & Disagree \\
\hline 22 & Functional fire extinguishers & 1.0 & 2.1 & 1.55 & Disagree \\
\hline 23 & Adequate safety display notices & 2.0 & 2.0 & 2.00 & Disagree \\
\hline 24 & Protective safety equipment & 2.3 & 2.70 & Disagree \\
\hline 25 & Adequate fire alarms & 3.1 & 3.05 & Agree \\
\hline
\end{tabular}




\begin{tabular}{|c|c|c|c|c|c|}
\hline 26 & Adequate waste disposal & 3.3 & 3.2 & 3.25 & Agree \\
\hline 27 & Tools/equipment are returned after used & 2.1 & 2.2 & 2.15 & Disagree \\
\hline 28 & Adequate maintenance of machines & 2.3 & 2.0 & 2.15 & Disagree \\
\hline
\end{tabular}

Table 2 above revealed that the responses of the respondents related to the status of infrastructure and facilities of fine and applied arts curriculum in human capacity building in colleges of education in North-eastern Nigeria rated item 9, 12, 13, 25 and 26 agreed with a grand mean ranging from $3.05-3.25$ while the remaining items disagreed with, with a grand mean ranging from $2.00-2.70$.

Table 3. T- test of difference between lecturers and students on the status of fine and applied arts curriculum in human capacity building in colleges of education in North-eastern Nigeria.

\begin{tabular}{|c|c|c|c|c|c|c|c|}
\hline S/No & SUBJ & MEAN & STD & N & DF & T-CAL & T-CRIT \\
\hline 29 & LECT. & 2.49 & 4.32 & 12 & 60 & 3.22 & 2.0003 \\
\hline 30 & STD & 2.73 & 3.44 & 50 & 60 & & \\
\hline
\end{tabular}

Table 3, revealed that the t-calculated (3.22) is greater than t-critical table value (2.0003), the result of this test suggested that there is significant difference between the responses of lecturers and students. Since the t-calculated is greater than the t-critical value, null hypothesis was then rejected.

Table 4. T-test of the difference between lecturers and students on the status of infrastructures and facilities in colleges of education in North-eastern Nigeria.

\begin{tabular}{|c|c|c|c|c|c|c|c|}
\hline S/No & SUBJ & MEAN & STD & N & DF & T-CAL & T-CRIT \\
\cline { 1 - 6 } 31 & LECT. & 2.30 & 3.93 & 12 & 60 & 3.711 & 2.0003 \\
\cline { 1 - 5 } 32 & STD & 2.32 & 2.50 & 50 & 60 & & \\
\hline
\end{tabular}

Table 4, revealed that the t-calculated (3.22) is greater than t-critical table value (2.0003), the result of this test indicated that there is significant difference between the responses of lecturers and students. Since the t-calculated is greater than the t-critical value, null hypothesis was then rejected. 


\section{FINDINGS / DISCUSSION}

Analysis in Table 1 under the status of the curriculum shows that provision for subsidiary courses was strongly agreed upon by both lecturers and students. While, items two to eight disagreed. This clearly shows that the curriculum status provided room for subsidiary courses. On the other hand curriculum comprises of other trades, it is reviewed to current issues, it is in harmony with others, it provides skill acquisition, it is comprehensive, and it has met the needs of Nigerians and finally the curriculum contains current issues. All these were totally disagreed with. It is in line with Uzoagba (1985) who affirmed that lessons lack systematic scheme of work, principles and teaching skills, the art curriculum is more departmentalized and a school may or may not teach arts, and individual students may or may not choose to take it. He further states that in most cases where art is taught, much is left to the individual teacher's taste and initiative, because of lack of a common well planed curriculum of arts and good method of teaching.

The second research question is the status of infrastructure and facilities required in our colleges of education which if properly put in place will definitely enhance the teaching of fine and applied arts in our colleges. The subjects agreed that there are adequate workshops, halls, classes, fire alarms and adequate waste disposal units, and are relevant in making students acquire competent skills needed. While on the contrary view, the subjects disagreed with the remaining items which were rated below the decision rule. Aina (2000) affirmed that the performance of students at national technical certificate (art inclusive) examinations revealed very disturbing statics attributable to: utter neglect, poor funding, inadequate resources and poor management of infrastructure and facilities: Ishiaka (1997) also lamented that the problem faced by vocational and technical education which art is part, includes inadequate funding leading to inadequacy of human and material resources.

\section{CONCLUSION}

In conclusion, this paper has revealed that the curriculum of fine and applied arts of colleges of education in Nigeria lacks competency in making students self reliant or to secure and hold job. There is the need for urgent review of the curriculum by improving its status and providing infrastructures and facilities lacking in order to create standard colleges of education not only in north-eastern states, but Nigeria as a whole. This is because the curriculum of fine and applied arts education in Nigeria leaves so much to be desired in this globalised computer age.

\section{Recommendation}

1. There is the need for an analytical curriculum.

2. There is the need to strengthen the curriculum of fine and applied arts education in order to meet up with the global challenges.

3. Proper measures should be taken in making sure that the curriculum is being implemented effectively and efficiently.

4. There is need for making curriculum materials available for the attainment and achievement of the lofty objectives of fine and applied arts.

5. The teachers of fine and applied arts should be made stakeholders in the programming and curriculum development. 
6. The body responsible for accreditation should endeavor that if not all, ninety percent of the requirement is met before such a college is considered.

\section{References}

[1] Afolabi P. (2001). Justification for Creative Arts Education: A keynote address delivered at the conference/exhibition organized by the department of Fine and Applied Arts, College of Education, Lkere-Ekiti on Creative Arts Education for Integration and Sustainable Development in Nigeria. 2001.

[2] Aina O. (2000). Technical and Vocational Education: vision and action. Blue print and master plan-Federal Ministry of Education 2001-2010.

[3] Dogara U. S., Joel M. M. (2012). Assessing the Relevance of Technical Education Curriculum in Job Creation and National Security. A paper presented at the $2^{\text {nd }}$ national conference of school of vocational and technical education. College of Education, Azare, Bauchi State.

[4] Domba A. (2005). Science D esign, Art and Craft. Lagos: Movic Publishing Company Ltd.

[5] Ishiaka K. (1997). Technology Education and Vision: a keynote address delivered at $2^{\text {nd }}$ National conference of Technology Education FCE Gusau.

[6] Mutari A. K., Ademola A. (2007). Delivery of Technical and Vocational Education "Necessary Reforms in Technical and Vocational Education System for Sustainable Development in Nigeria. NATT Book of proceedings $20^{\text {th }}$ Annual National Conference Kaduna, pp. 536.

[7] Nuru Y. A. (2008). NBTC Advocated Vocational and Technical Education for Vision 2020. Daily Trust Newspaper. Thursday, January $24^{\text {th }}, 2008$, Q2

[8] Okoro M. O. (2006). Principles and methods of vocational and Technical Education, Nsuka: University trust publishers.

[9] Saidu S. (2007). Functional Curriculum for National Economic Empowerment and Development, Nigeria Journal of Science and Educational Research, 1(14); 265-269.

[10] Sambo A. A (2005). Research methods in Education Stiring-Horden Publishers (Nig) Ltd. Ibadan.

[11] Umar I. Y., Ma'aji A. S. (2010). Repositioning the Facilities in Technical Colleges Workshop for Efficiency. A case study of North Central Nigeria. Journal Stem Teacher Educational, 47(3).

[12] Uzoagba I. N. (1985). Understanding Art in General Education: Africans-FEP Publishers (Nigeria) Limited.

[13] Williams P. S (2009). Skill Acquisition: A tool for youth development and empowerments. NATT Book of Proceedings $22^{\text {nd }}$ Annual National Conference Bauchi. pp. 184.

[14] Halima Sidi Bamall, International Letters of Social and Humanistic Sciences 8(1) (2014) 50-55. 
[15] Elizabeth Morenikeji Titilayo Adediran, Albert Oluyomi Kehinde, International Letters of Social and Humanistic Sciences 8(1) (2014) 66-75.

[16] S. A. Kazeem, K. Y. Balogun, International Letters of Social and Humanistic Sciences 8(2) (2014) 108-119.

[17] Nneka Rita Udoye, Victor Etim Ndum, International Letters of Social and Humanistic Sciences 8(2) (2014) 130-139.

[18] Sanusi L. Sa'adatu, International Letters of Social and Humanistic Sciences 8(2) (2014) 140-147.

[19] Benedicta Ehi Momodu, International Letters of Social and Humanistic Sciences 13 (2014) 64-70.

[20] Adebowale Adeyemi-Suenu, International Letters of Social and Humanistic Sciences 13 (2014) 89-94.

[21] Adebowale Adeyemi-Suenu, International Letters of Social and Humanistic Sciences 14 (2014) 1-6.

[22] Roghaieh Fathi, International Letters of Social and Humanistic Sciences 19 (2014) 24-34.

[23] Zahra Karami Baghteyfouni, Mehri Raoufi, Mahnaz Asadihaghighat, Hamidreza Mahmodian, Mohamad Khaledian, International Letters of Social and Humanistic Sciences 20 (2014) 1-8.

[24] Dennis Agama Eka, International Letters of Social and Humanistic Sciences 8(2) (2014) 170-182.

[25] Nayereh Shahmohammadi, International Letters of Social and Humanistic Sciences 8(2) (2014) 183-191.

[26] Godwin E. Itua, International Letters of Social and Humanistic Sciences 8(3) (2014) 200-207.

[27] Rowland U. Aleshi, Clementina N. Iloh, International Letters of Social and Humanistic Sciences 8(3) (2014) 208-216.

[28] Hannatu Abdullahi, International Letters of Social and Humanistic Sciences 8(3) (2014) 217-223.

[29] Fowoyo Joseph Taiwo, International Letters of Social and Humanistic Sciences 8(3) (2014) 244-251.

[30] Abdulrahaman W. Lawal, International Letters of Social and Humanistic Sciences 3 (2014) 53-59.

[31] Alaba E. Dare, International Letters of Social and Humanistic Sciences 3 (2014) 73-79.

[32] Grema Maina Bukar, Yohanna A. Timothy, International Letters of Social and Humanistic Sciences 4 (2014) 9-21.

[33] M. N. Modebelu, F. K. Igwebuike, International Letters of Social and Humanistic Sciences 4 (2014) 40-48.

[34] Akor Isaiah Akem, Victor Tavershima Ukeli, International Letters of Social and Humanistic Sciences 4 (2014) 49-59. 
[35] Sule Maina, International Letters of Social and Humanistic Sciences 4 (2014) 87-96.

[36] Nwachukwu Uche Emma, International Letters of Social and Humanistic Sciences 5 (2014) 1-12.

[37] Peace Ebele Ilechukwu Chukwbikem, International Letters of Social and Humanistic Sciences 8(1) (2014) 1-17.

[38] Odo John Ogar, International Letters of Social and Humanistic Sciences 8(1) (2014) 28-33. 